\title{
Can Non-discrimination Law Change Hearts and Minds?
}

\author{
Anita Böcker*
}

\section{Abstract}

A question that has preoccupied sociolegal scholars for ages is whether law can change 'hearts and minds'. This article explores whether non-discrimination law can create social change, and, more particularly, whether it can change attitudes and beliefs as well as external behaviour. The first part examines how sociolegal scholars have theorised about the possibility and desirability of using law as an instrument of social change. The second part discusses the findings of empirical research on the social working of various types of non-discrimination law. What conclusions can be drawn about the ability of non-discrimination law to create social change? What factors influence this ability? And can nondiscrimination law change people's hearts and minds as well as their behaviour? The research literature does not provide an unequivocal answer to the latter question. However, the overall picture emerging from the sociolegal literature is that law is generally more likely to bring about changes in external behaviour and that it can influence attitudes and beliefs only indirectly, by altering the situations in which attitudes and opinions are formed.

Keywords: law and society, social change, discrimination, non-discrimination law, positive action

\section{Introduction}

Can law change 'hearts and minds', and can it change attitudes and beliefs as well as external behaviour? This question, often in tandem with the question of whether law should attempt do so, has preoccupied sociolegal scholars for ages, and it is also a central question in this article. The article examines, first, how sociolegal scholars have theorised and written about the strengths and limitations of law in general in creating (different types of) social change. Second, it focuses on the ability of non-discrimination law to create social change. What have been the findings of empirical research on the effects of (different types of) non-discrimination law? When and under what circumstances and conditions can it create (what types of) social change?

The article does not aim to provide a complete or systematic overview of the literature. The first part is based predominantly on a survey of introductions to the disci-

* Anita Böcker is associate professor of Sociology of Law at Radboud University, Nijmegen. pline of law and society, nearly all of which devote a chapter to the relationship between legal change and social change or the use of law as an instrument of social change. Laws and legal rules aimed at eliminating discrimination or promoting equality are typical examples of law being used as an instrument of social change. The second part of the article is based on a survey of empirical sociolegal studies of the effects of non-discrimination law. I searched not only for studies evaluating (from a top-down perspective) the effectiveness of, or compliance with, specific laws or legal rules or rulings, but also, or rather, for studies shedding light (from a bottom-up perspective) on the social working of nondiscrimination law, i.e. its effects on the shop floor of social life, where it is just one factor among others.

A shortcoming of the literature I reviewed for the first part of the article is that it tends to use the concept of social change in a rather loose manner. An explicit definition is often not provided. ${ }^{1}$ For the purpose of this article, the discussion of the concept by Joel and Mary Grossman, although somewhat older, is still useful. The Grossmans distinguished three types or levels of social change. The first level or type would consist of changes in patterns of individual behaviour. The second level would involve changes in group norms and/or changes in the relations of individuals or groups to each other or to the political, economic or social system. The third type or level would consist of changes in a society's basic values or mores; the Grossmans note that this is 'the most difficult to describe and undoubtedly the most difficult to achieve'. ${ }^{2}$ The three levels are, of course, interrelated and should be viewed on a continuum rather than as discrete types. For the question of whether law can change 'hearts and minds', the second and third types of social change are most relevant. They are also most difficult to identify, and it is even more difficult to identify the role played by law in these processes.

Law's impact on social change may be direct or indirect. A direct impact occurs when law itself affects behaviour. Changes in group norms and group relations and changes in basic attitudes and beliefs are typically an indirect or 'ripple' effect of legal change. ${ }^{3}$ The impact of legal change on these types of social change can hardly

1. Cf. R. Cotterrell, The Sociology of Law: An Introduction (1993), at 47.

2. J.B. Grossman and M.H. Grossman, 'Introduction', in J.B. Grossman and M.H. Grossman (eds.), Law and Change in Modern America (1971) 1, at 6.

3. L. Friedman, Impact. How Law Affects Behavior (2016), at 48; S.E. Barkan, Law and Society (2018), at 151. 
be measured, as law is just one factor among others that play a role in such processes. Moreover, legal change is often itself an effect of social change. There is often a reciprocal relationship between legal and social change in the sense that social forces or movements and social change help to put in place new legislation that, in turn, spurs further change.

As a final preliminary remark, although this article focuses on the role that law can play in creating social change and promoting equality, it should be recognised that throughout history there have been more examples of law being used to maintain the status quo. Law, as many introductions to the sociology of law point out, has a tendency towards conservatism:

Once a scheme of rights and duties has been created by a legal system, continuous revisions and disruptions of the system are generally avoided in the interests of predictability and continuity. ${ }^{4}$

Moreover, certain kinds of discrimination are inherent in law itself: 'The law in its majestic equality ... forbids the rich as well as the poor from sleeping under bridges, begging in the streets, and stealing bread. ${ }^{5}$

\section{Theorising on the Relation between Law and Social Change}

This section examines how sociolegal scholars have theorised about law's ability to bring about social change. Over the last two centuries, views on the relationship between law and social change have changed. The prevailing view has long been that law merely reflects the sense of justice and the current mores and opinions of the population; rather than an independent force acting on society, law was seen as an aspect of society. This started to change in the late eighteenth century, a period of rapid social change in Europe. Jeremy Bentham (1748-1832), English philosopher and jurist, and one of the founders of utilitarianism, advocated that legal reforms should respond quickly to new social needs. However, he also held that 'legislation has the same centre with morals, but not the same circumference', ${ }^{6}$ meaning that law and morality have a common goal, namely to regulate people's behaviour in such a way as to produce the greatest possible sum of good, but differ in their extent:

[T] here are many acts useful to the community which legislation ought not to command. There are also

\footnotetext{
S. Vago, Law and Society (2012), at 21-2.

D. Black, The Behavior of Law (1989), at 72.

J. Bentham, An Introduction to the Principles of Morals and Legislation (1907) (first printed 1780), at 60
}

many injurious actions which it ought not to forbid, although morality does so. ${ }^{7}$

One reason for this difference is, according to Bentham, that legal duties and offences must be defined in a very clear and precise manner, which is simply not possible for many moral duties or vices. ${ }^{8}$

In the early twentieth century, the prevailing view on the relationship between law and society still held that legal change could not have an impact unless it conformed to prevailing trends in social mores and norms. In his classic work Folkmays, American sociologist William Graham Sumner (1840-1910) posited that 'legislation cannot make mores' (often misquoted as 'stateways cannot change folkways'). ${ }^{9}$ Sumner wrote, among other topics, about race relations in southern US society, pointing out that after the civil war, the whites had not been 'converted from the old mores', and that attempts to control the new order by legislation had been vain. ${ }^{10}$ Sumner did not claim that it is absolutely impossible to induce a change in mores or customs, but he emphasised that legislation alone would not restrain people from doing what they have always believed to be right or appropriate or make them do something they have always thought wrong or unwise. Lawmakers should therefore estimate the probable support for proposed changes and the amount of enforcement power probably required. ${ }^{11}$

In the course of the twentieth century, law, and especially legislation, came to be seen as separate from the society it regulates, and it came to be used as an instrument for social engineering in ways these earlier writers could not have imagined. ${ }^{12}$ This development is mirrored in twentieth-century sociolegal writing. Arguments against the possibility and desirability of using law to induce social change were, as Yehezkel Dror put it, 'overruled by the facts of reality', and the growing use of law as an instrument of social change came to be seen as a characteristic of modern society that required intensive study. ${ }^{13}$ Many twentieth-century sociolegal scholars reflected on the advantages and limitations of law as an instrument of social change. Most of them, however, avoided making generalised statements about the role of law in social change. ${ }^{14}$

Section 2.1 provides an overview of what contemporary law and society scholars regard as strengths and limitations of law as an instrument of social change. Section

\footnotetext{
Ibid., at 60 .

Ibid., at 60-1

9. W.G. Sumner, Folkways: A Study of the Sociological Importance of Usages, Manners, Customs, Mores, and Morals (1960) (first printed 1907), at 81.

10. Ibid., at 81

11. H.V. Ball, G.E. Simpson \& K. Ikeda, 'Law and Social Change: Sumner Reconsidered', 67 American Journal of Sociology 532, at 538 (1962).

12. Cf. Cotterrell, above n. 1, at 44-6; S. Vago and S.E. Barkan, Law and Society (2018), at 208-10.

13. Y. Dror, 'Law and Social Change', 33 Tulane Law Review 787, at 796 (1958-1959)

14. Cf. J. Morison, 'How to Change Things with Rules', in S. Livingstone and J. Morison (eds.), Law, Society and Change (1990) 5.
} 
2.2 takes a brief look at attempts to specify factors and conditions maximising the impact of legal change. Section 2.3 examines John Griffits' attempt to develop a systematic sociological theory of the social impact of law.

\subsection{Strengths and Limitations of Law as an Instrument of Social Change}

Most sociolegal scholars would agree that there are a few important advantages of law in creating social change. ${ }^{15}$ The first is the binding force of law. Particularly in parliamentary democracies, people tend to consider law as something that should be obeyed. An important factor is the belief in legitimate authority, or, as Lawrence Friedman put it:

People obey the law, 'because it is the law.' ... If they were forced to explain why, they might refer to some concept of democracy, or the rule of law, or some other popular theory sustaining the political system. ${ }^{16}$

Steven Vago regarded the socialisation process as an important factor in the binding force of law: 'People, in general, are brought up to obey the law. The legal way of life becomes the habitual way of life.' Moreover, as this habitual way of life 'requires less personal effort than any other and caters well to a sense of security ... it also pays to follow the law'. ${ }^{17}$

Another advantage of law as an instrument of social change is that it is backed by mechanisms of enforcement and sanctions' ${ }^{18}$ Alternatively, as Friedman put it,

Law has its hidden persuaders - its moral basis, its legitimacy - but in the last analysis it has force, too, to back it up.... This is the fist inside its velvet glove. ${ }^{19}$

Some people may obey the law merely to avoid punishment. However, most sociolegal scholars would probably agree with Tom Tyler's assessment that people, in general, obey the law not primarily because they believe they will be punished for disobedience but because 'they believe it is proper to do so'. ${ }^{20}$

Other scholars pointed to law's ability to shape bargaining and dispute handling processes outside the courts, in everyday social life. Parties in a dispute 'do not bargain in a vacuum .... They bargain in the shadow of the law'. The outcome that the law will impose if no agreement is reached casts its shadow over private negotia-

15. See, e.g., Vago, above n. 4, at $319 \mathrm{ff}$.

16. L. Friedman, The Legal System: A Social Science Perspective (1975), at 114.

17. Vago, above n. 4 , at 323

18. Ibid., at 320 .

19. L.M. Friedman and G.M. Hayden, American Law: An Introduction (2017), at 263-4.

20. T. Tyler, Why People Obey the Law (1990); T. Tyler, 'Multiculturalism and the Willingness of Citizens to Defer to Law and to Legal Authorities', 25 Law \& Social Inquiry 983, at 984 (2000). tions; it gives the parties in a dispute certain 'bargaining endowments'. ${ }^{21}$

Because of these strengths, and particularly because of law's legitimate authority, social movements may see litigation as an effective tool in helping advance their aims. Steven Barkan emphasised the indirect benefits of legal mobilisation:

[Even if it] does not produce significant tangible results in and of itself, it may still give aggrieved groups a sense of legal entitlement by suggesting that their claims and grievances are in fact their legal rights. This sense may in turn give them new hope for social and political change and spur members of these groups to work for such change. ${ }^{22}$

Law thus offers important advantages as an instrument of social change. However, the lists of limitations that can be found in introductions to the field of sociology of law are much longer.

Some limitations are inherent in the law itself. First, as was already argued by Sumner, legislation cannot enforce itself. In an article entitled The Limits of Effective Legal Action, Roscoe Pound pointed out that a statutory rule (unlike common-law rules) is made a priori and is not necessarily a 'living rule' when it is laid down. Statutory rules cannot enforce themselves:

Human beings must execute them, and there must be some motive setting the individual in motion to do this above and beyond the abstract content of the rule and its conformity to an ideal justice or an ideal of social interest. ${ }^{23}$

Pound concluded that lawmakers must therefore study how to ensure that people will have a motive for mobilising the law in the face of the opposing interests of others in infringing it'. ${ }^{24} \mathrm{~A}$ second limitation, which was already mentioned by Bentham, is that if laws are to be applied and enforced by courts or other legal actors, a high degree of clarity must be sought. Pound therefore held that law, unlike morals, can only be used to control external, observable behaviour. He gave as an example that law cannot protect against purely subjective mental suffering because of 'obvious difficulties of proof'.$^{25}$

Other limitations originate from a variety of forces that directly or indirectly may reduce law's ability to create change. Steven Vago distinguished between social, psy-

21. R.H. Mnookin and L. Kornhauser, 'Bargaining in the Shadow of the Law: The Case of Divorce', 88 Yale Law Journal 950, at 968 (1979). It should not be assumed, however, that disputes are always transformed into the language of the law; in many disputes, people may choose between several different types of norms. See H. Jacob, 'The Elusive Shadow of the Law', 26 Law \& Society Review 565 (1992).

22. Barkan, above n. 3, at 160 .

23. R. Pound, 'The Limits of Effective Legal Action', 3 American Bar Association Journal 55, at 69 (1917); see also Cotterrell, above n. 1, at $51 \mathrm{ff.;}$ M. Berger, Equality by Statute: The Revolution in Civil Rights (1968), at 219 .

24. Pound, ibid., at 70

25. Ibid., at 66 
chological, cultural and economic factors. Social factors include vested interests:

The acceptance of almost any change through law will adversely affect the status of some individuals or groups in society, and to the degree that those whose status is threatened consciously recognize the danger, they will oppose the change. ${ }^{26}$

Habit is a psychological factor that may act as a barrier to change: 'Once a particular form of behavior becomes routinized and habitual, it will resist change.' 27 Cultural factors include ethnocentrism: '[F]eelings of superiority by whites have hindered integration efforts in housing, employment and education among many areas in the context of race relations. ${ }^{28}$ Last but not least, economic factors may form a barrier to changes that might otherwise be readily adopted. Vago gives as an example that the administrative costs associated with affirmative action programmes in the United States were resisted in many academic circles and contributed to demands for modification of a variety of laws affecting higher education. $^{29}$

Law's ability to create social change also depends on the type of change sought. Yehezkel Dror distinguished between 'emotionally neutral' and 'expressive and evaluative' areas of activity, arguing that the latter are far more resistant to changes imposed by law. Dror referred to studies of the reception of western European law in Turkey, which showed that

aspects of social action of a mainly instrumental character, such as commercial activities, were significantly influenced by new law, while those aspects of social action involving expressive activities and basic beliefs and institutions, such as family life and marriage habits, were very little changed despite explicit laws trying to shape them. ${ }^{30}$

Other authors likewise argued that law is 'generally more likely to bring about changes in what may be called external behavior' ${ }^{31}$ According to some, the use of law to change deep-rooted attitudes and beliefs by imposing legal duties that require such changes is fraught with problems. Legal sanctions are useless and may even have perverse effects. ${ }^{32}$ Allott refers to the notion of 'superficial conformism'. People who feel that their opinions are contradictory to the 'official and general line of thought' will keep these opinions to themselves and conform in their outward response to what they think is the permitted line. ${ }^{33}$

33. A.N. Allott, The Limits of Law (1980), at 231.
}

A few authors are more optimistic about law's ability to change basic attitudes and beliefs. ${ }^{34}$ According to Vago, 'changes in external behavior are, after a while, usually followed by changes in values, morals, and attitudes'. ${ }^{35}$ Friedman refers to experimental studies that showed that people tend to change their minds about moral propositions when they find out what 'the law' has to say. ${ }^{36}$ Thus, it would seem that the law's 'legitimate authority' can wield influence over attitudes as well as behaviour. Of course, this presupposes that people are aware of what the law says - which in practice is often not the case. ${ }^{37}$

Even optimistic authors assume that law can influence attitudes and beliefs only indirectly. According to Friedman, the impact of legal change is 'mediated and influenced by some sort of learning process - a complicated process - that takes place within society'. ${ }^{38}$ William M. Evan assumed that legal change may produce changes in attitudes and beliefs through two interrelated processes: a process of institutionalisation (the establishment of a norm with provisions for its enforcement) and a process of internalisation (the incorporation of the value(s) implicit in the law). 'Law ... can affect behavior directly only through the process of institutionalization; if, however, the institutionalization process is successful, it, in turn, facilitates the internalization of attitudes or beliefs.' 39

\subsection{Attempts at Specifying Conditions That Maximise the Impact of New Laws}

Various scholars have tried to specify the conditions under which a new law is likely to effectively influence behaviour and, perhaps, attitudes. Evan, writing with the US experience with law and racial desegregation in mind, hypothesised that seven conditions are necessary for law 'to perform an educational function' - conditions that, he stressed, are not always possible to achieve:

1. The source of the new law should be perceived as authoritative.

2. The rationale for the new law should clarify its continuity and compatibility with existing institutionalised values.

3. Publicity surrounding the new law should emphasise that similar laws have proven helpful in other countries or settings.

4. The enforcement of the law must be aimed at making the change in a relatively short time, so as to minimise the chances of the growth of organised or unorganised resistance.

34. For a more extensive overview, see A. Kok, 'Is Law Able to Transform Society', 127 South African Law Journal 59, at 71 ff. (2010).

35. Vago, above n. 4, at 329.

36. Friedman (1975), above n. 16, at 115.

37. Friedman (2016), above n. 3, at 14

38. Ibid., at 72

39. W.M. Evan, 'Law as an Instrument of Social Change', in A.W. Gouldner and S.M. Miller (eds.), Applied Sociology: Opportunities and Problems (1965) 285 , at 286 
Atomistic individualism: Society is seen as made up of individuals who behave like rational actors, bound together by the state organisation and not by anything else.

Perfect legal knowledge: The social space between the state and the individual is conceived of as a normative vacuum through which the commands of the legislature pass unmediated and untransformed by intervening social rules and structures on their way to the individual.

Legal monism: The state is assumed to have an effective monopoly over the regulation of interaction that (except in some extremely deviant situations such as the mafia) excludes other sources of regulation as important influences on behaviour.

Legislative autonomy: The legislature is treated as external to and independent of the social context in which legal rules are effective.
People are fundamentally social beings: Legal rules are addressed to social beings acting in a specific social context, not to asocial rational actors seeking to maximise their preferences.

Legal knowledge is socially contingent: The message about the law that ultimately comes to an actor's attention is seldom the same as what the legislature intended. The transmission process is a transformation process in which the message gets simplified and otherwise distorted and enriched with all sorts of additional information.

Legal pluralism: The state is but one of many sources of regulation, and for individuals engaged in social interaction, the behavioural expectations of the state are frequently less well known, less clear and less pressing than those of other sources of regulation that are closer to the scene.

Inseparability of legislation from social life: Legislation is an integral part of processes of ordering, conservation and change in society; it is not a distinct and autonomous force acting on those processes.
5. The enforcement agents must themselves be committed to the behaviour required by the law, even if not to the values implicit in it.

6. Positive as well as negative sanctions should be used to help ensure compliance.

7. Effective protection and resources should be provided for people who would suffer from evasion or violation of the law by other people. ${ }^{40}$

Similar listings, mostly based on common sense and inductive reasoning on the basis of a few specific cases, were drawn up by other scholars. ${ }^{41}$ Although a wealth of empirical studies on law's impact on behaviour have been undertaken in the half-century since Evan wrote his still often-cited essay, a recent review concludes that it is hardly possible to draw general conclusions about the conditions under which new laws are most likely to have an impact: 'Much more research is needed. More replications. More attempts at pulling the strands together. Otherwise, everything depends. On time. On place. On situation. ${ }^{42}$ Friedman's synthesis study nevertheless shows that the potential for legal impact is greater when four factors coincide: ample publicity, a proper mix of rewards and punishments, peer pressure supporting obedience to the new law, the new law appealing to the sense of conscience and prevailing moral views of the public at which it is aimed.

40. Ibid., at 285

41. See J.A. Kok, A Socio-Legal Analysis of the Promotion of Equality and Prevention of Unfair Discrimination Act 4 of 2000 (2008); Kok (2010), above n. 34. Kok made a detailed analysis of four of these requirements of effective laws in his study of the potential effectiveness of a South African non-discrimination law.

42. Friedman (2016), above n. 3, at 249

\subsection{Griffiths' Theory of the Social Working of Law}

An attempt to develop a systematic sociological theory of the social impact of law was made by John Griffiths. Griffiths was motivated by puzzlement:

It is hard to understand how anyone could ever expect a legislated rule to have any effect on behavior. After all, as it leaves the legislative body a law seems to be nothing more than so many ink marks on paper. $^{43}$

Griffiths called his theory 'the social working approach' and set it against traditional 'instrumentalist' approaches to legislation. According to Griffiths, lawmakers and authors of impact studies tend to make four untenable assumptions about society and social life and the place therein of legal rules. ${ }^{44}$ Griffiths' theory of the social working of legal rules consists of four propositions that are simply the opposite of the basic assumptions of the instrumentalist paradigm:

Griffiths' depiction of the instrumentalist paradigm in legal impact studies is slightly caricatural. Moreover, there are many examples of sociolegal studies that do take a sociological approach. However, there have not been many attempts at developing a systematic theory of the relationship between legal and social change, and an important merit of Griffiths' social working approach is that it forces researchers to look 'bottom-up', not 'topdown'. It is not the intention of the lawmaker, but the

43. J. Griffiths, 'The Social Working of Legal Rules', 48 Journal of Legal Pluralism 1, at 4 (2003).

44. Ibid., at 16 
'shop floor of social life', where law is only one factor amidst other factors, that should be at centre stage.

This 'shop floor of social life' can be described and analysed as a 'semi-autonomous social field' (SASF). Sally Falk Moore developed this concept in a classic article on the relationship between law and social change. ${ }^{45}$ Every society, Moore argued, consists of overlapping SASFs; every individual belongs to various SASFs at any given time. An SASF can generate rules and has the means to induce or coerce compliance internally, but it is also vulnerable to rules and decisions emanating from the state and other SASFs. Examples of SASFs are families, workplaces, churches or branches of industry. According to Moore, 'the various processes that make internally generated rules effective are often also the immediate forces that dictate the mode of compliance or non-compliance to state-made legal rules'. ${ }^{46}$ Studying the operation of SASFs in which new legal rules have to unfold their effects would thus enable researchers to gain a better understanding of how legal change is really effected. Griffiths' approach was applied in several studies of the social working of non-discrimination law, which will be discussed next. ${ }^{47}$

\section{Empirical Studies on the Social Impact of Non- discrimination Law}

This section turns to the findings of empirical research on the social impact of non-discrimination law. What conclusions can be drawn from this literature about the effects (or lack thereof) of non-discrimination law and the factors that explain these effects?

Non-discrimination law comes in many forms and can be used to promote equality and combat discrimination in different (direct or indirect) ways. Legislation and legal rules can be used to prohibit discrimination and provide remedies for (individual) victims; to oblige or encourage employers or other actors to take affirmative action; or to open up institutions (e.g. marriage) for groups that used to be barred from these institutions. Moreover, non-discrimination law consists not only of legislation but also of case law. In the United States, in particular, social movements have used litigation to pursue social change, and court decisions have played an important role in bringing about policies and legislation aimed at reducing racial and other discrimination.

45. S. Falk Moore, 'Law and Social Change. The Semi-Autonomous Socia Field as an Appropriate Subject of Study', 7 Law and Society Review 719 (1973).

46. Ibid., at 721

47. J. Griffiths, 'The Social Working of Anti-Discrimination Law', in T. Loenen and P. Rodriguez (eds.), Non-Discrimination Law: Comparative Perspectives (1999) 313; T. Havinga, 'The Effects and Limits of AntiDiscrimination Law in The Netherlands', 30 International Journal of the Sociology of Law 75 (2002).
This section discusses findings from studies on each of these types of non-discrimination law. Section 3.1 focuses on legislation based on an 'individual rights model'. Section 3.2 focuses on affirmative action law. Both types of non-discrimination law have been the subject of evaluation studies. However, rather than effectiveness or compliance evaluations, I selected studies that shed light on the social working of non-discrimination law, i.e. its effects on the shop floor of social life, where it is just one factor of many that influence behaviour. The next three subsections contain examples of other types of non-discrimination law. Section 3.3 examines the role of civil society groups in making non-discrimination law a reality on the ground. Section 3.4 examines how rules and processes within social fields may resist or support state-made non-discrimination rules. Section 3.5 discusses the findings of studies that focused specifically on law's ability to eliminate or reduce prejudice.

\subsection{Legislation Based on an 'Individual Rights Strategy'}

Many non-discrimination laws are based on what has been called an 'individual rights strategy' ${ }^{48}$ or an 'individual justice model' ${ }^{49}$ This type of legislation gives individuals who belong to disadvantaged groups the right to equal treatment. To uphold this right, an individual has to take action. He or she can ask the offending party to comply with the law, and, should this claim be unsuccessful, file a complaint with a specialised agency or bring the case to court. The enforcement thus depends primarily on the action of individual victims of discrimination.

Various empirical studies have shown the limitations of this type of legislation. A first limitation is that claims and complaints tend to be limited to overt and direct forms of discrimination. For example, in the Netherlands, in the early years of the gender equality legislation, many complaints concerned job advertisements stating a preference for, or excluding, male or female applicants. One will hardly find such advertisements any more today. Legislation prohibiting discrimination may thus be effective against overt forms of discrimination. However, other (more covert, indirect or systemic) forms of discrimination, if unlawful at all, are practically impossible to recognise for individual victims.

Other limitations arise because victims who do recognise that they have been or are being discriminated, often prefer the options of 'lumping it', 'avoidance' or 'exit', rather than confront the offending party and invoke the protective measures of law. In a classic study, based on in-depth interviews with women (black, Hispanic and white) and men (black and American Indian) in the

48. S. Macaulay, 'Lawyers and Consumer Protection Laws', 14 Law and Society Review 115 (1979); Griffiths (1999), ibid.; Havinga, Ibid.

49. C. McCrudden, 'International and European Norms Regarding National Legal Remedies for Racial Inequality', in S. Fredman (ed.), Discrimination and Human Rights: The Case of Racism (2001) 251. Other models distinguished by McCrudden are the 'group justice model' and 'equality as participation'. 
United States who had experienced discrimination, Kristin Bumiller highlighted three factors that make victims of discrimination refrain from taking action and mobilising the law:

- The power disparity between the parties involved (for example, between an employee and her employer).

- The refusal to consider oneself a victim. Discrimination is seen as inevitable in the lives of disadvantaged groups; they develop an 'ethic of survival'.

- Victims' perception of the law: law is on their side (forbidding discrimination), but is it able to really help them, or will legal intervention worsen the situation? ${ }^{50}$

The same or similar barriers have been found in other studies. ${ }^{51}$

Bumiller's study built on a large survey, in which thousands of randomly selected respondents were asked what grievances they had experienced in the past three years and how they had dealt with these grievances. ${ }^{52}$ The researchers distinguished five stages in the development of a dispute from grievance to court filing: 1) grievance; 2) claim (the aggrieved party confronts the offending party and asks for redress); 3) dispute (the offending party rejects the claim); 4) the aggrieved party contacts a lawyer; 5) court filing. Only a small fraction of all grievances in their study reached the last stage. However, the pattern for discrimination grievances (one in seven respondents reported grievances involving racial, sexual, age, or other discrimination in employment, education or housing) clearly differed from the general pattern: grievances were less likely to lead to claims; claims were more likely to be rejected; and disputes were less likely to lead to contacts with lawyers and court filings. 'The impression is one of perceived rights which are rarely fully asserted. When they are, they are strongly resisted and pursued without much assistance from lawyers or courts. ${ }^{53}$ Findings such as these illustrate the limitations of an individual rights strategy in legislating against discrimination.

Griffiths' social working theory was applied in a study of the effects and limits of the Dutch 1994 Equal Treatment Act, which prohibited discrimination on grounds of religion, belief, political opinion, race, sex, nationality, heterosexual or homosexual orientation and civil status in the areas of employment and goods and services

50. K. Bumiller, 'Victims in the Shadow of the Law: A Critique of the Model of Legal Protection', 12 Signs 421 (1987).

51. E.g., B. Quinn, 'The Paradox of Complaining: Law, Humor, and Harassment in the Everyday Work World', 25 Law \& Social Inquiry 1151 (2000); J. Verstraete, D. Vermeir, D. De Decker \& B. Hubeau, Een Vlaams antidiscriminatiebeleid op de private huurmarkt. De mogelijke rol van zelfregulering (2017); see also Kok (2008), above n. 41, at 12-13: "Many South Africans have internalised discrimination and do not perceive discriminatory incidents perpetrated against them as discrimination, but as "the way things are" .... The majority of South Africans lack confidence in the courts and the justice system and have inadequate access to courts."

52. R.E. Miller and A. Sarat, 'Grievances, Claims, and Disputes: Assessing the Adversary Culture', 15 Law \& Society Review 525 (1980).

53. Ibid., at 545 provision. Tetty Havinga examined five factors or conditions that might play a role in the social working of legislation based on an individual justice model:

- Whether a specialised agency has been set up to investigate complaints, what (other) competences it has and how it uses these competences. The study found that the Equal Treatment Commission at the time took a reactive rather than a proactive approach, investigating complaints and handing down rulings but not using its competences to initiate investigations or to enforce compliance with its rulings in court. This was due to resource limitations, but partly also to the commission's preference for giving priority to its judicial tasks; at any rate it meant that the mobilisation of the law depended largely on members of the protected groups and civil society organisations.

- Whether knowledge about the legal rules is communicated to potential offenders and potential victims. The study showed that five years after its entry into force, most actors at 'the shop floor of social life' had only a vague idea about the contents of the Equal Treatment Act.

- Whether there are civil society organisations that inform, activate and support members of the protected groups in claiming their right to equal treatment. The study showed that especially in cases concerning racial discrimination, specialised (nondiscrimination) NGOs played an important role.

- Whether expert legal assistance is available for victims of discrimination. The study found that in cases concerning racial discrimination, legal assistance was mostly provided by the aforementioned specialised NGOs. Possible explanations could be the lack of competent lawyers, the relatively low monetary stakes and the expectations of victims of racial discrimination.

- Whether the social fields in which the legal norms are supposed to work tend to support or oppose the legal norms. The study found that there was more support (at least ideologically) within public sector organisations as compared with private firms, and within larger as compared with smaller firms. ${ }^{54}$

\subsection{Affirmative Action Legislation}

Griffiths hypothesised that 'more is often to be expected from regulatory approaches that do not depend on the creation of individual rights that require mobilization and enforcement on the shop floor'. ${ }^{5}$ Equal employment opportunity (or employment equity) laws are based on a 'non-individual rights' approach. This type of legislation obliges employers to engage in proactive employment practices to improve the employment opportunities of members of under-represented groups (e.g. women, racial minorities, persons with disabilities). Particularly in the United States, affirmative action laws

54. Havinga (2002), above n. 47.

55. Griffiths (1999), above n. 47, at 10 
have also been used to fight discrimination in the areas of education and housing.

An obvious strength of this strategy is that its effectiveness does not have to depend on actions of individual members of disadvantaged groups. It may thus be better suited to combating indirect and systemic forms of discrimination. However, a potential risk is that (some) members of majority groups perceive 'affirmative' or 'positive action' as a threat to their position. They may thus be provoked to resistance:

Few workplace policies are as controversial or divisive as affirmative action programs. They attempt to redress or reduce historical forms of discrimination based on demographic distinctions among employees, but they simultaneously mandate social categorizations on the basis of those same distinctions. ${ }^{56}$

Critics claim that affirmative action laws and policies stigmatise minority students or employees as being less than fully qualified, when in fact they may be well qualified. Another, related potential weakness is that affirmative action relies and depends on the collection and processing of data regarding membership of the designated groups. Employment equity laws require employers to collect, maintain and report information about how racial minorities, women and/or persons with disabilities are represented across occupational categories and salary levels within their workforce. They are required to identify areas of under-representation and to set goals for improvement by comparing the information about their own workforce to data on the availability of racial minorities, women and/or people with disabilities in relevant labour markets. The effectiveness of affirmative action thus depends on the quality and accuracy of both types of data.

Various studies have evaluated the effects of employment equity laws in Canada and the Netherlands, among other countries. Studies of the impact of Canada's federal employment equity legislation found that it did make a difference for the representation rates of the designated groups, though more so for those of women and visible minorities than for those of aboriginal people and persons with disabilities. Moreover, progress differed across sectors and occupations. ${ }^{57}$ Carol Agocs examined two contrasting explanations for the limited results. The first was that the legislation itself was flawed. An essential weakness would be its reliance on data collected through self-identification. Increases in the representation of, in particular, aboriginal people and persons with disabilities might be partly attributable to changes in the rates of self-identification. However, Agocs found it more likely that the limited results stem-

56. D.A. Harrison, D.A., Kravitz, D.M. Mayer, L.M. Leslie \& D. Lev-Arey, 'Understanding Attitudes Toward Affirmative Action Programs in Employment: Summary and Meta-Analysis of 35 Years of Research', 91 Journal of Applied Psychology 1013, at 2013 (2006).

57. C. Agocs, 'Canada's Employment Equity Legislation and Policy, 1987-2000: The Gap between Policy and Practice', 23 International Journal of Manpower 256 (2006); C. Agocs (ed.), Employment Equity in Canada. The Legacy of the Abella Report (2014). med 'from a failure of employers to implement the Act, and of government to enforce it and hold employers accountable for lack of compliance'. ${ }^{58}$ This gap between policy and practice might in turn be explained by the lack of political will to provide adequate provisions for monitoring and enforcing compliance. For example, employers covered by the Employment Equity Act were subject to compliance audits by the Canadian Human Rights Commission, but the Act forbade the commission to impose quotas on employers even when they were not in compliance. Enforcement by the commission was also hampered by resource limitations. Employers with more than 100 employees were required to implement employment equity as a condition for bidding on contracts with the federal government, but the review process appeared to be extremely lenient. In addition, Agocs pointed to ongoing structural changes in the labour market and the nature of work:

Employment equity policy assumes long-term jobs with somewhat specialized job descriptions, not the 'flexible' and contingent jobs favored by many employers today, or the very small businesses or selfemployment arrangements that are becoming common, particularly among women. ${ }^{59}$

Trends such as these might worsen the position of the designated groups in the labour market, and the current employment equity legislation was not likely to address them effectively.

The Netherlands had employment equity legislation in place in the years 1994-2004. The objective of the Dutch Employment Equity Act (Wet Bevordering Evenredige Arbeidsdeelname Allochtonen) was to improve the position of ethnic minorities in the labour market. The Dutch law was modelled on the Canadian legislation. However, it did not rely on data based on self-identification but on 'objective' data, i.e. information on the country of birth of one's parents. A study of the drafting stage and the first five years of the legislation found that there was a lot of resistance against the collection and registration of these data, most fiercely from employers (because of the administrative burden) but also from employees and others (who had principal objections to the registration of data on people's race or ethnicity). ${ }^{60}$ Moreover, the study found that the Dutch law's approach was weakened by political compromises even more than was the case with its Canadian counterpart. The drafters of the law did not attach meaningful sanctions to non-compliance with the requirements imposed by the law. Publicity was expected to be an effective measure to achieve compliance. Employers were obliged to deposit annual reports with the Cham-

58. Agocs (2006), ibid., at 270.

59. Ibid., at 274 .

60. P. Jonkers, Diskwalificatie van wetgeving. De totstandkoming en uitvoering van de Wet Bevordering Evenredige Arbeidsdeelname Allochtonen (Wbeaa) (2003); A.P. Jonkers and P.E. Minderhoud, 'The Dutch Employment Equity Act: An Analysis from the "Poldermodel" Perspective', in F. van Loon and K. van Aeken (eds.), 60 maal recht en 1 maal wijn. Liber Amicorum prof. dr. Jean van Houtte (1999) 530. 
bers of Commerce, and third parties had a right of access to these reports. However, many employers did not comply and got away without any repercussions. ${ }^{61}$ The representation rates of the designated groups nevertheless improved during the years the legislation was in force. The favourable economic situation probably helped a lot in achieving these results.

Studies on the implementation of affirmative action legislation in the United States have likewise shown the importance of enforcement of requirements. Executive Order 11246 requires firms that do business with the federal government to take affirmative action to ensure that job applicants are employed and that employees are treated during employment without regard to their race, colour, religion, sex or national origin. A study of its effects concluded that during the initial years, when this affirmative action requirement was vigorously enforced, the representation rates of black men and women increased significantly faster in contractor than in noncontractor firms. However, this progress stopped in the 1980s, when enforcement budgets and staff were reduced. ${ }^{62}$ Another American study, on affirmative action programmes for minority students, found evidence that affirmative action programmes can stigmatise minority students. However, the researchers concluded that this finding 'tells us less about the inherent weakness of affirmative action than about the poor fashion in which programs are carried out'. ${ }^{63}$ Referring to social psychological studies, they suggested that the power of negative stereotypes can be defused through programmes of 'wise intervention'. Such programmes should, among other elements, provide 'an emphasis on challenge rather than remediation in learning, conveying to students their potential for growth rather than their accumulated deficiencies', and 'affirmation of minority students' belonging on the campus and their routine acceptance as members of the scholarly community'. ${ }^{64}$

The picture emerging from these and other studies on the impact of affirmative action laws and policies is mixed. However, a clear conclusion is that their effects and effectiveness depend to a large extent on how they are implemented and enforced and, moreover, on how the purposes behind the requirements are communicated to all actors involved.

\subsection{Mobilisation of the Law (and the Protected Groups) by Civil Society Groups}

The importance of the involvement of civil society in making non-discrimination law a reality on the ground has been underlined most clearly in studies of the American civil rights movement. Charles Epp argued that 'rights are not gifts'; they 'originate in pressure

61. Jonkers, ibid

62. J.S. Leonard, 'The Impact of Affirmative Action Regulation and Equal Employment Law on Black Employment', 4 Journal of Economic Perspectives 47 (1990)

63. C.Z. Charles, M.J. Fischer, M.A. Mooney \& D.S. Massey, 'Affirmative Action Programs for Minority Students: Right in Theory, Wrong in Practice', 55 Chronicle of Higher Education 29 (2009), https:// www.chronicle.com/article/Affirmative-Action-Programs/35122.

64. Charles et al., ibid. from below in civil society, not leadership from above' ${ }^{65}$ Epp attributed the growth in civil rights cases decided by the US Supreme Court to the emergence of groups such as the National Association for the Advancement of Colored People and the American Civil Liberties Union:

Only certain kinds of pressure from below, particularly organized support for rights litigation, are likely to support sustained judicial attention to civil liberties and civil rights; and support from judicial elites is hardly irrelevant. ${ }^{66}$

In a study of the impact of the US Supreme Court's decision in Bromn v. Board of Education, which outlawed segregation in public schools, Gerald N. Rosenberg also emphasised the pivotal role of the civil rights movement. According to Rosenberg, even if the court had not acted as it did, 'the existence and strength of pro-civilrights forces at least suggests that change would have occurred, albeit at a pace unknown' ${ }^{67}$

The same factor, i.e. the involvement of civil society groups, was found to be of crucial importance in making Swedish non-discrimination legislation work. Reza Banakar compared two Swedish non-discrimination laws: the Equality between Women and Men Act (EWMA) and the Act against Ethnic Discrimination (AED). They were comparable in many respects; in fact, the AED was modelled on the EWMA. However, the AED was much less mobilised and applied than the EWMA. Banakar found that this could not be explained by differences between the two laws or how they were enforced by ombudsmen. His explanation was that the two laws

constitute two different forms of legislation, the one emerging from below as a result of an ongoing rights discourse and acting bottom up, the other being imposed from above to introduce a rights discourse and acting top down. ${ }^{68}$

The women's movement was actively involved in both the making of the EWMA and its enforcement once it had entered into force. The AED lacked such a support structure. It was enacted by the Swedish government in response to international pressure to satisfy the legal standards set by various UN and ILO conventions. The groups it aimed to protect were diffuse and barely organised; they were hardly involved in the making of the law and did not have the organisational capacities to mobilise it once it was in force.

65. C.R. Epp, The Rights Revolution. Lawyers, Activists, and Supreme Courts in Comparative Perspective (1998), at 197.

66. Epp, ibid., at 197

67. G.N. Rosenberg, The Hollow Hope: Can Courts Bring About Social Change? (1991), at 157.

68. R. Banakar, 'When Do Rights Matter? A Case Study of the Right to Equal Treatment in Sweden', in S. Halliday and P. Schmitt (eds.), Human Rights Brought Home. Socio-Legal Perspectives on Human Rights in the National Context (2004) 165, at 184 
The aforementioned study of the Dutch Employment Equity Act came to a similar conclusion. Unlike its Canadian counterpart, the Dutch law was introduced through political pressure from above, not through pressure from below. The drafters of the law expected that organisations of the designated groups would actively mobilise the law once it was in place, but they did not. Trade unions and works councils were also very hesitant to help enforce the law, because they lacked resources and, moreover, did not want to harm their relations with employers. ${ }^{69}$

The role of civil society organisations has also been examined in studies on the implementation and/or mobilisation of European equality law in $\mathrm{EU}$ member states. Anna van der Vleuten examined how European gender equality law was implemented in more and less willing member states. Her study shows that unwilling member states can be forced to comply when they are put under pressure ('squeezed' or 'sandwiched') by supranational and domestic actors simultaneously. ${ }^{70}$ Constanza Hermanin sought to explain why, fifteen years after its entry into force, the European Racial Equality Directive was very rarely used to claim racial discrimination at the Court of Justice of the European Union (CJEU). Her analysis of jurisprudence of national courts in three member states showed that the absence of CJEU case law was related to scarce litigation for fighting racial and ethnic discrimination at the national level. This scarcity of domestic litigation was, in turn, related to the limited presence, organisational capacities and keenness and capacity to engage in legal strategies of specialised civil society organisations. ${ }^{71}$

These and other studies ${ }^{72}$ illustrate that civil society groups can play a crucial role in making non-discrimination law a reality on the ground. Non-discrimination laws may be enacted without their involvement, but the chances of 'law in the books' becoming 'law in action' are higher when they are involved in the lawmaking process and perceive the law as 'theirs' once it is in force. The mobilisation of non-discrimination rights often depends on whether there are NGOs that can inform, activate and support members of the protected groups. The enforcement of affirmative action requirements sometimes likewise depends on the actions of civil society organisations.

69. Jonkers, above n.60, at $123 \mathrm{ff}$.

70. A. van der Vleuten, 'Pincers and Prestige: Explaining the Implementation of EU Gender Equality Legislation', 3 Comparative European Politics 464 (2005)

71. C. Hermanin, 'Whither Judicial Europeanization? The Case of the Race Equality Directive', in B. Witte, J. Mayoral, U. Jaremba, M. Wind \& K. Podstawa (eds.), National Courts and European Law: New Issues, Theories and Methods (2016) 239.

72. E.g., A. Böcker, 'Racial Discrimination in The Netherlands', 17 New Community 603 (1991); N. O'Brien, 'Social Rights and Civil Society: "Giving Force" without 'Enforcement', 34 Journal of Social Welfare and Family Law 459 (2012).
3.4 Support or Resistance within Relevant Social Fields

Non-discrimination law has to unfold its effects at the shop floor of social life, in what may be considered SASFs. ${ }^{73}$ Social fields have their own, internally generated rules, norms and routines, and the means of inducing or coercing compliance. These internal rules and processes may hamper or promote compliance with rules emanating from the state. State-made non-discrimination rules may be supported and incorporated into the prevailing norms and structures, but they are more likely to be resisted, at least initially.

Studies on the civil rights movement in the United States have shown that the Supreme Court's 1954 decision in Bromn v. Board of Education met with fierce resistance in the southern United States. Rosenberg's study of the impact of this federal court ruling led him to conclude that "while there is little evidence that Brown helped produce positive change, there is some evidence that it hardened resistance to civil rights among both elites and the white public' ${ }^{74}$ Resistance to change grew not only in education, but also in other areas. Rosenberg posited that the courts offer only a 'hollow hope' for achieving social change. Victories in court may not prompt much change, as the opposing parties often fiercely resist these changes, and the courts lack effective enforcement powers. According to Rosenberg, 'Bromn's major positive impact was limited to reinforcing the belief in a legal strategy for change of those already committed to it. ${ }^{, 75}$ However, other authors emphasised the importance of this indirect benefit of legal mobilisation. Although Bromn did not quickly end school segregation, it did give African Americans in the southern United States new hope and helped spur the massive civil rights protests that captured the nation's attention in the following decade. ${ }^{76}$ A study on women's struggles for pay equity yielded a similar conclusion. Michael McCann found that the actual gains fell short of the high hopes created by the movement's legal victories; employers' resistance effectively limited pay equity achievements. But women gained a new sense of their rights as workers and their discrimination as women workers; this encouraged them to become more active in labour unions and to press for reforms in areas beyond pay equity. ${ }^{77}$ Another study showed that although it did not end discrimination, the Americans with Disabilities Act helped to improve the self-image and to enhance the career aspirations of people with disabilities. ${ }^{78}$

Resistance to change may also take a passive or covert form. Studies of the social impact of the Dutch 1994 Equal Treatment Act found that, in general, the norm of equal treatment enjoyed a high degree of support in

73. See Section 2.3 above

74. Rosenberg, above n. 67, at 155; see also Barkan, above n. 3, at 158

75. Rosenberg, above n. 67, at 156.

76. Berger, above n. 23; Barkan, above n. 3, at $157 \mathrm{ff}$.

77. M. McCann, Rights at Work. Pay Equity Reform and the Politics of Legal Mobilization (1994); Barkan, above n. 3, at 160.

78. D.M. Engel and F.W. Munger, Rights of Inclusion: Law and Identity in the Life Stories of Americans with Disabilities (2003). 
the social fields targeted by the law. However, members of these social fields tended to assume that their work practices and routines were in accordance with the law, without really knowing (or asking) what the law required in specific situations. They simply believed that discrimination did not occur in their organisation or industry. The researchers noted, however, that some of the selection criteria and procedures used by, for example, banks or insurance companies, might very well constitute indirect discrimination under the law. ${ }^{79} \mathrm{~A}$ recent study of discrimination in the rental housing market in the Netherlands showed that these findings were still valid. Landlords and rental brokers were not aware that some of their usual practices might be in breach of the non-discrimination legislation. In their everyday practice, discrimination was not really an issue; they were much more preoccupied with issues such as the risk of tenants growing drugs in their properties. $^{80}$

Various other factors and characteristics of social fields may influence compliance with non-discrimination law. One such factor is whether the 'definition of the situation' of the lawmakers is shared within the relevant social fields. In the case of the Dutch Employment Equity Law, employers did not believe that discrimination was an important factor in the disadvantaged position of ethnic minorities in the labour market. This certainly did not help to gain their support and compliance. ${ }^{81}$ Other factors are the anticipated costs of compliance and whether the areas of activity concerned are of a mainly instrumental character or of an expressive and evaluative character. ${ }^{82}$ These factors may explain why large employers were found to be more likely to adapt their employment policies and procedures to comply with the Dutch Equal Treatment Act than small employers. ${ }^{83}$

However, such modifications may represent cosmetic rather than deep changes. In this regard, it is interesting that in the United States one effect of the 1964 Civil Rights Act was that large employers created internal procedures for resolving discrimination complaints, as an alternative to formal legal channels. A study in which complaints handlers were interviewed showed that, on the one hand, such internal procedures encouraged the resolution of many complaints that would find no remedy under law. In this sense, law could be said to cast a broad shadow over the internal dispute resolution pro-

79. T. Havinga, 'Aanbieders van goederen en diensten en gelijke-behandelingswetgeving', in I.P. Asscher-Vonk and C.A. Groenendijk (eds.), Gelijke behandeling: Regels en realiteit. Een juridische en rechtssociologische analyse van de gelijke-behandelingswetgeving (1999) 371; T. Havinga and C.A. Groenendijk, 'De sociale werking van gelijkebehandelingswetgeving', in I.P. Asscher-Vonk and C.A. Groenendijk (eds.), Gelijke behandeling: Regels en realiteit. Een juridische en rechtssociologische analyse van de gelijke-behandelingswetgeving (1999) 495, at 508; Havinga (2002), above n. 47, at 86.

80. A. Böcker, A. Terlouw \& E. Özdemir, Discriminatie bij de verhuur van woningen? Een verkennend onderzoek naar verklaringen en de mogelijke aanpak (2019).

81. Jonkers, above n. 60

82. See Section 2.1 above

83. Havinga (2002), above n. 47. cess. At the same time, however, the shadow of law was eclipsed by organisational concerns. Law was found to play a very peripheral role in the complaint handlers' orientations toward discrimination complaints. They were focused on resolving complaints to restore smooth employment relations and tended to recast discrimination claims as typical managerial problems. Lauren Edelman concluded that ' $[\mathrm{w}]$ hile the assimilation of law into the management realm may extend the reach of law, it may also undermine legal rights by deemphasizing and depoliticizing workplace discrimination'. ${ }^{84}$

In a later study, Edelman argued that an important reason for the limited success of equal employment opportunity law is that employers create policies and programmes such as non-discrimination policies, anti-harassment policies, diversity programs 'that promise equal opportunity yet often maintain practices that perpetuate the advantages of whites and males', ${ }^{85}$ and that even courts defer to these symbolic structures:

The widespread acceptance of organizational policies that symbolize equal opportunity ... extends into the legal realm, where courts too often focus on the presence of organizational policies that signify nondiscrimination more than they attend to evidence that minorities and women face systematic disadvantages at work. ${ }^{86}$

These research findings are in line with the basic assumptions of Griffiths' social working approach, in particular the assumption of the socially contingent character of legal knowledge (state-made rules are mediated and transformed by intervening social rules and structures on their way to members of SASFs) and the assumption of legal pluralism (state-made rules often have to compete with the internal rules of social fields, and the latter rules may be clearer and more binding for the members of these social fields).

\subsection{Can Non-discrimination Law Change People's Hearts and Minds?}

A few studies have focused specifically on the question of whether non-discrimination law can eliminate or reduce prejudice. They tend to assume that it can do so only indirectly.

American studies mostly refer to the example of desegregation (in the army, schools, housing projects) to argue that changes required by law have lessened prejudice by altering the situations in which attitudes are formed or reinforced. As Morroe Berger put it in his study on the role of law in the area of civil rights:

[L]aw does not change attitudes directly, but ... by altering the situations in which attitudes and opinions are formed, law can indirectly reach the more private

84. L.B. Edelman, H.S. Erlanger \& J. Lande, 'Internal Dispute Resolution: The Transformation of Civil Rights in the Workplace', 27 Law \& Society Review 497, at 497 (1993).

85. L.B. Edelman, Working Law: Courts, Corporations, and Symbolic Civil Rights (2016), at 14.

86. Ibid., at 15. 
areas of life it cannot touch directly in a democratic society. ${ }^{87}$

Berger cited Gordon Allport's contact hypothesis, which holds that interpersonal contact can reduce prejudice. It is important to note, however, that Allport himself emphasised that only under certain conditions would interpersonal contact reduce prejudice:

Prejudice ... may be reduced by equal status contact between majority and minority groups in the pursuit of common goals. The effect is greatly enhanced if this contact is sanctioned by institutional supports ..., and provided it is of a sort that leads to the perception of common interests and common humanity between members of the two groups. ${ }^{88}$

These facilitating conditions (equal status, common goals, intergroup cooperation and institutional support) may well be managed in experiments. Experimental research has indeed yielded evidence that externally imposed desegregation can reduce prejudice over time. The authors of a recent study presented their findings as a refutation of Sumner's contention that legislation cannot change mores. ${ }^{89}$ Unfortunately, however, the conditions outlined by Allport are much more difficult to meet in real social life. Prospects are most favourable in the area of education.

Another psychological mechanism is the cognitive dissonance mechanism. Robert L. Kidder referred to this mechanism to explain the decline in expressions of racial prejudice and hatred found in surveys in the southern United States after the Supreme Court's 1954 school desegregation decision:

$[\mathrm{P}]$ eople cannot persist in behaving in ways that are incompatible with their beliefs and values... If the law prevents people from acting consistently with old beliefs and values, then they abandon the old beliefs and adopt new ones which fit the actions they find themselves doing. ${ }^{90}$

However, he questioned the reliability and validity of the surveys' results.

A recent American study has found that legalising samesex marriage has accelerated the acceptance of homosexuality. ${ }^{91}$ The researchers examined each US state's level of bias against gay people before and after the legalisation of same-sex marriage in that state. They found that, although bias against gay people was already on the

87. Berger, above n. 23, at 217, 229

88. G.W. Allport, The Nature of Prejudice (1954), at 281.

89. A. Eller, D. Abrams \& M. Koschate, 'Can Stateways Change Folkways? Longitudinal Tests of the Interactive Effects of Intergroup Contact and Categorization on Prejudice', 72 Journal of Experimental Social Psychology 21 (2017).

90. R.L. Kidder, Connecting Law and Society. An Introduction to Research and Theory (1983), at 119

91. E.K. Ofosu, M.K. Chambers \& E. Hehman, 'Same-Sex Marriage Legalization Associated with Reduced Implicit and Explicit Antigay Bias', 116 Proceedings of the National Academy of Sciences 8846 (2019). decline, it began to drop more quickly after the legalisation of same-sex marriage. This finding suggests that legal change, the symbolic message of law, can sway public opinion, improving tolerance for members of stigmatised groups. However, there was some evidence of a backlash in states that only legalised same-sex marriage following federal legalisation. The researchers therefore added the caveat that "[f]or laws to change minds, it is possible that the laws must be perceived as intrinsically motivated by the people'. ${ }^{92}$ A similar study was conducted in Europe. Like its US counterpart, it found that the legal recognition of same-sex relationships was associated with an increase in favourable attitudes towards sexual minorities. The effects were widespread across demographic groups. The researchers concluded: 'Our results suggest that laws can exert a powerful influence on societal attitudes. ${ }^{93}$

Kidder would probably not share this optimism. As said, he questioned the reliability and validity of surveys that measured a decline in racist attitudes in the years after the US Supreme Court's decision in Brown $v$. Board of Education. Kidder argued that there were other changes, for example in the composition of the southern population, which might explain the measured change in attitudes. Moreover, people might just have learnt to conceal racist attitudes when answering survey questions. ${ }^{94}$ Last but not least, Kidder pointed out that even a genuine shift in people's attitudes towards racial minorities may not put an end to institutionalised racism. Referring to the example of school desegregation in the United States, he argued that regardless of

[w] hether whites care or not for minority groups and racial equality ... their pursuit of economic security and the best housing they can afford produces patterns of residential segregation which are reflected in school populations. ${ }^{95}$

This also raises the question of what is more important, changes in (patterns of) behaviour or changes in attitudes and beliefs? It can be argued that, overall, disadvantaged groups will benefit first of all from changes in 'external' behaviour; they will benefit most when they are no longer confronted with practices of discrimination in major areas of life.

\section{Concluding Remarks}

There is no unequivocal answer to the question of whether law can change 'hearts and minds'. The overall picture emerging from the sociolegal literature is that

92. J.M. Chen, 'When Laws Change Minds', Psychology Today, 23 April 2019, https://www.psychologytoday.com/ie/blog/race-in-new-world/ 201904/when-laws-change-minds (last visited 28 February 2020)

93. C.G. Aksoy, C.S. Carpenter, R. De Haas \& K. Tran, ‘Do Laws Shape Attitudes? Evidence from Same-Sex Relationship Recognition Policies in Europe', EBRD Working Paper 2018:219.

94. Kidder, above n. 90 , at 125 .

95. Ibid., at 125-6. 
law can do so only indirectly, by changing the situations in which attitudes and beliefs are formed.

The research literature on the social impact of nondiscrimination law shows that its effects and effectiveness depend largely on how it is implemented and enforced, whether there are civil society groups that help to enforce it and whether the social fields in which it has to unfold its effects support it. Conditions for achieving compliance are not always favourable. Enforcement by governmental agencies is often hampered by resource limitations, and civil society organisations may not be keen on and capable of mobilising the law against more powerful parties. The norm of equal treatment is widely supported in principle, but in everyday social practice it has to compete with other, more established rules, routines and practices within social fields.

On a more positive note, the research literature also confirms the notion of reciprocity between legal change and social change. This implies that if the timing is right, legal interventions may reinforce and accelerate changes in social norms. As Griffiths put it,

[As] long as the legislator does not march too far in advance of developments in social norms, legislation can help to articulate them, thus making the applicable norms clear and indisputable, at which point informal control can assume the task of enforcement. $^{96}$

To put it in one sentence, law alone cannot deal effectively with social problems such as discrimination, but it can be an important ally or instrument for social change. 